\title{
Irish Playwrights and the Dunedin Stage in 1862: Theatre Patrons Performing Civility
}

\author{
PETER KUCH
}

Irish Plays on the Dunedin Stage in $\mathbf{1 8 6 2}$

A first-rate actor of Irish characters is indispensible on a London Stage.

Cumberland's British Theatre, 1828.

Between 1862 and 1869 there were some 300 performances of Irish plays in Dunedin's theatres.

Kuch, Irish Society for Theatre Research, 2010.

A mere 14 years after it was founded by Presbyterians as a distinctly Scottish city that was "in the world but not of the world," Dunedin possessed two splendid theatres that during their first decade of operation staged some 300 performances of Irish plays and plays by Irish playwrights. How did this happen? Why Irish plays? Why Irish playwrights? And why were two theatres, with capacities of 1500 and 1330 persons, opened in Dunedin a year before Otago Boys High School was founded, five years before the foundations of First Church were laid, and seven years before the Provincial Council turned its attentions to establishing a University? ${ }^{1}$ Initially, it was the theatres that were a source of civic pride. According to an 1862 issue of the Otago Witness, Dunedin possessed "two of the handsomest theatres in the Australian colonies." "While there are doubtless many explanations for this rush to build theatres, the short answer is that the city was overtaken by the very world it had sought to isolate itself from. But this is an answer that invites explanation.

First, it has to do with what was on offer on stage. It has been well established by theatre historians that Irish playwrights (particularly Dion Boucicault) and Irish plays (particularly comedy and melodrama) dominated the nineteenth-century stage- whether in Dublin or London or New York. ${ }^{3}$ It is also well known that, by the time the Theatre Royal and The Princess Theatre were opened in Dunedin, the "legitimate drama" ${ }^{4}$ had become widely if not firmly established as the secular vehicle for social and cultural improvement. For example, the editor of the Daily Southern Cross assured his Auckland readers on 8 July 1856: "Believing, as we do, that the drama in good hands, has an elevating, rather than a demoralizing tendency - that it is calculated to assist the moral and mental development of a community; believing, also, that, a taste for dramatic entertainments having already been acquired, the people of Auckland would feel a deprivation, were the Theatre to be finally closed." 5

And this was a view that was widely held, particularly in the colonies, where, by the mid-nineteenth century, building and supporting a magnificent theatre for the "rational enjoyment" of "legitimate drama" was considered a mark of civic maturity. From the latter half of the nineteenth century, colonial theatre-going became a way of consuming and performing metropolitan culture. Progress in communication and in travel meant that plays which had been successful in London and New York could, within a few months of opening, be enjoyed by audiences in Sydney, Melbourne, Dunedin and Auckland. Between the arrival of Dunedin's first settlers in 1848 and the opening of its theatres in 1862, Royal patronage, embourgeoisement, venture capital, theatre design, technology, and the growth of a professional international tour circuit had all played their part in combating the late eighteenthand early nineteenth-century image of the theatre as a venue for sensationalism, tawdry spectacle, riot and bawdry. This is not to claim that such concerns did not continue to hover in 
the wings. In 1859, for example, Mr T.S. Bellair of the Bellair-Hill Company is reported to have reassured the audience of the Royal Theatre in Auckland that:

The feeling that anything to do with the theatre must be immoral unless it was educational was very deeply engrained in the colonies and even after this time reassurances were still necessary. Fifteen years earlier British Theatres had certainly fallen on evil days and ways but now, with Queen Victoria herself a faithful patron and regular playgoer, ${ }^{6}$ times were changing. The London theatre had become fashionable. It was even considered in some quarters as a serious art form! ${ }^{7}$

In fact, the evil days of the mid-1840s to which Mr Bellair refers were even then being counteracted by a series of legislative measures introduced in the late 1820 s and early $1830 \mathrm{~s}$ that either indirectly or directly sought to foster the "legitimate drama" and make it more accessible to a wider public. For example, the 1829 Catholic Emancipation Act and the 1832 Reform Act, apart from attempting to mitigate sectarianism and extend the franchise, had the indirect effect of empowering an emerging middle class, whether Catholic or Protestant, to be more confident in accessing public spaces and public venues and to make greater demands that such spaces and venues were respectable. There were also direct attempts to improve the public image of theatres and theatrical performance, though not all of these were immediately successful. The 1833 Dramatic Literary Property Act, ${ }^{8}$ which was intended to "give a lofty character to the drama" by using property law to ensure that a playwright's work was adequately remunerated, failed in the short term when the agency set up to collect fees, the Dramatic Authors' Society, "simply abandoned any commercial distinctions between the values of tragedy and burlesque, comedy and melodrama in favour of the cold, economic logic of supply and demand." A similar fate befell many of the recommendations from the 1832 House of Commons Enquiry into Dramatic Literature, which was expressly convened to reform the theatre, as it took more than a decade for what survived the committee process to pass into legislation and receive Royal assent as the Licensing Act of 1843 (6\&7 Vict.c.68). Until then, the patent theatres-Drury Lane, Covent Garden and the Haymarket (the last solely during the summer) - were the only venues for public entertainment where spoken drama could legally be performed. Non-patent theatres, held in thrall by legal precedence and almost a century of tradition, were therefore obliged to resort to burlettas if they wished to have dialogue performed on stage - burlettas being short comic ballad operas in which it was considered that the ratio of spoken to sung dialogue did not infringe the monopoly held by the patent theatres.

Though the patent theatres for the most part successfully defended their monopoly until the early 1840 s by threatening legal action against any manager who dared to produce spoken drama, they were eventually powerless against the large sums of money that could be earned by catering for the hunger for theatrical entertainment that gripped mid-Victorian Britain. Even the legislation that the patent theatres believed guaranteed their monopoly eventually proved vulnerable. The Surry, for example, one of the more aggressive of the non-patent theatres, was able to outmanoeuvre Drury Lane and Covent Garden by exploiting the vagueness of the term burletta. Elliston, the actor-manager, effectively rebutted every threat of legal challenge by simply pointing out that because the ratio of spoken to sung dialogue in the burletta had not been precisely defined, the amount of dialogue spoken on stage was open to interpretation. In the event, it was audience demand and box-office takings, and not the law courts, that determined who triumphed in the struggle between the patent and non-patent theatres.

Both the demand for theatrical entertainment and the confused state of the theatre are succinctly captured in a paragraph from London's Theatrical Observer of 26 May 1831:

At the theatre royal, Drury Lane, we have Timour the Tartar and the horses. At the theatre royal, Covent Garden, we have the Life and Death of Buonaparte, as a mere spectacle accompanied by every kind of catch-shilling gew-gaw, and some horses; 
while, on the other hand, we find at Sadler's Wells, Romeo and Juliet, Katharine and Petruchio; at the Surrey, Richard III, several other of Shakepeare's plays and Cumberland's Jew, with Elliston; and finally, at the new City Theatre in Milton Street (alias Grub) the Merchant of Venice; Shylock, Mr Kean!! ${ }^{10}$

What this list of performances and venues, and the double exclamation marks, express is astonishment at the way the competition for audiences had driven the patent theatres to resort to spectacle in an attempt to recapture audiences from a non-patent theatre that was illegally staging the "legitimate drama" with such luminaries as the greatest contemporary interpreter of Shakespeare, Edmund Kean (1787-1833). ${ }^{11}$ After 1843, of course, a list of performances and venues might be the same as above, or equivalent to it, but what would be different would be the subtext of legality. But the greatest difference, as I will show, is the extent to which the theatre became a contested public space for the performance of civility-particularly in the sense of "relating to culture and civilized behaviour," that is, in the OED's definition, "behaviour or speech appropriate to civil interactions, politeness, courtesy, consideration."

\section{Theatre Comes to the Colony}

In broad terms, the triumph of the non-patent theatres meant that even the colonial stage was legally entitled to stage "legitimate drama" well before the John Wickliffe and the Philip Laing were nosing their way up the harbour towards the "Otago block." 12 While it is unlikely that Captain Cargill had the theatre in mind when he addressed the 350 Scots and English colonists on landing at Dunedin that "the eyes of the British Empire, and ... of Europe and America" were upon them to see how a system of colonization based on "liberal and enlightened principles" would work, it was in fact those very liberal and enlightened principles that a mere 14 years later would be called upon to justify the building of the Theatre Royal and the Princess Theatre.

By then, theatre had been enjoyed in fits and starts and in one form or another for almost 20 years in several of the colonies that would come to comprise New Zealand. Auckland is thought to have been the site of the first public "entertainment"-a "smoke concert" in the Large Room of the Blue Bell Inn on 13 November 1841 courtesy of a Professor of Elocution, Mr D. Osborne. Five weeks later he mounted the first dramatic performance, The Lawyer Outwitted by his Apprentice, in which he played the leading role. ${ }^{13}$ Wellington, it seems, claims the honours for the first theatre, in the sense of a purpose-built venue. Constructed by James $\mathrm{H}$. Marriott and named the Royal Victoria Theatre, it opened on 12 September 1843. Though constructed as an annexe to the Ship Hotel, it was nevertheless designed according to the traditional style of the tiny Georgian theatres that by then were scattered throughout the United Kingdom, North America and the larger Australian towns. ${ }^{14}$ The first professional troupe to come to New Zealand appears to have been the Buckingham players, ${ }^{15}$ who arrived in Auckland from Sydney in late 1843, and staged Crossing the Line and Lovers Quarrels ${ }^{16}$ at an improvised venue before supervising the construction of their own building in Shortland Crescent. ${ }^{17}$ The first public petition in support of theatrical performance was presented to the Government of Canterbury in July 1858 after the Governing Committee of the Lyttelton Town Hall had refused to lease it to the Australian-based company of Mr and Mrs R.H. Cox. ${ }^{18}$ Finally, the first play by a major Irish playwright to be staged in New Zealand was the Foley and Jones production of Sheridan's The Rivals performed in June 1859 at the Olympic Theatre in Wellington. ${ }^{19}$ Though most of these "firsts" should be seen as declarations of intent rather than foundational events - regular performances in Auckland, for example, did not occur until the arrival of the Bellair Company from Sydney in November $1857^{20}$ - they nevertheless point to a widely held desire to see theatre establish itself in the colonies. 
There were also one or two tentative attempts to establish theatre in Dunedin prior to 1862. The Otago Witness of 25 August 1855 advised the "inhabitants of Dunedin and suburbs" that J. Nicholson, late of the Deptford Theatre, would give a dramatic reading of The Merchant of Venice at the Odd Fellows Hall. ${ }^{21}$ A short while later, the San Francisco Minstrels took in Dunedin on a tour of the South Island. ${ }^{22}$ Yet as late as 1858 , the citizens of this staunchly Presbyterian city were still debating whether or not to permit public music concerts-let alone theatre. In an effort to counter such fears the Otago Witness of 17 April for that year politely pointed out that "in Glasgow and in other towns, as well as in Edinburgh, weekly concerts have been established, which are conducted with spirit and enterprise, and with the strictest propriety. In Wellington, which is nearer our doors, we observe that the Philharmonic Society have resolved to give Concerts more frequently ... We do not see why Otago should be behind." 23

\section{Irish Playwrights and the Dunedin Stage in 1862}

In the event Dunedin was overtaken by the outside world. That event was an influx of people in search of substantial quantities of gold. As the Otago Witness for 11 January 1862 reported, "the arrival in the past four weeks of nearly 2000 immigrants has not been without its effect upon the province." 24 Musing on the possible impact of this influx on the "town" rather than the province, the editor noted that while there was a "very plentiful lack" of any amusement of any kind, it was "doubtless the want of a theatre" that to some extent deterred "theatricals from visiting Dunedin," a want shortly to "be supplied by the enterprise of some spirited Victorian speculators, who have been attracted to these shores." ${ }^{25}$ At the end of January, scenes from James Sheridan Knowles's The Hunchback ${ }^{26}$ were staged in a hall that for the occasion doubled as an improvised theatre. ${ }^{27}$ Knowles, from Cork, who was described as "short, burly and with an Irish brogue as thick as butter," had an international reputation. His credits included plays in which Edmund Kean had achieved success, while in his day, as an actor, Knowles was regarded as a rival to one of the other stage giants of the period, William Charles Macready $(1793-1873) .{ }^{28}$ But sometime in the late 1840s he had turned his back on the stage to become a Baptist preacher and the author of two virulently anti-Catholic works, The Rock of Rome; or, The Arch Heresy (1849) ${ }^{29}$ and The Idol Demolished by Its Own Priest (1852). ${ }^{30}$ So it is not surprising that The Hunchback, which had premiered in Covent Garden in 1832 and been regularly performed throughout the English-speaking world, was selected as the first play by an Irish playwright to be performed in a city divided between its desire for "rational entertainment" and its virulent prejudice against the theatre. ${ }^{31}$ And it is also not surprising that the mode of performance, set speeches from selected scenes delivered in a hall, would have appealed, as the event could be characterized as a dramatic recitation rather than acting on a stage.

In the meantime, on 11 February 1862, while observing that the "absolute lack of places of amusement" had had "the prejudicial effect" of "causing Dunedin to seem a gloomy place," the Otago Witness announced that plans were afoot to remedy the situation. Improvisation would prove the mother of necessity. Portable staging and seating would allow the town's main horse-bazaar to be "transformed into a theatre," to be known as the Royal Princess Theatre, "and back again [into a horse-bazaar] with almost the rapidity of a pantomime scene." ${ }^{32}$ Having opened on 5 March 1862, the Royal Princess Theatre produced three internationally wellknown plays by Irish playwrights in quick succession: Dion Boucicault's Don Caesar de Bazan and The Corsican Brothers, and J.B. Buckstone's Green Bushes. To what extent the Dunedin audience knew that Boucicault and Buckstone were Irish playwrights is an issue to which I will return.

By May 1862, a second theatre, the Theatre Royal, was being built adjacent to the Criterion Hotel at a cost of some $£ 3000$. Designed by Mr Chas G. Smith, who had been the 
architect for the Prince of Wales Theatre in Sydney and the Jenny Lind Theatre in San Francisco, it boasted a Tuscan-style façade, bench seats in the pit and stuffed seats in the boxes that provided accommodation for about 1500 persons, and a stage and an auditorium whose dimensions were respectively $40 \mathrm{ft}$ by $42 \mathrm{ft}$ and $42 \mathrm{ft}$ by $56 \mathrm{ft}$. At the same time negotiations were under way with the Melbourne-based impresario George Coppin for "a permanent company of performers of first-class order." 33 On Friday 4 July 1862 there was a subscription ball to celebrate the completion of the building, and on Saturday 12 July the theatre opened with a performance of Bulwer-Lytton's Lady of Lyons, which had been described in the notices as a "legitimate play in five acts." 34 Here at last was a temple to the arts in which the citizens of Dunedin could enjoy celebrity metropolitan culture and at the same time perform civility. Not surprisingly, both the Otago Witness and the Otago Daily Times were quick to advise patrons how to dress and how to behave.

By the first week in August, the Theatre Royal was staging its first internationally successful and indisputably Irish play-Boucicault's The Colleen Bawn. This was a three-act melodrama that for two-and-a-half years had been very much in the news. Opening at Laura Keen's Theatre in New York on 29 March 1860, it ran for 44 nights, netting its playwrightproducer-actor sufficient income to buy two houses in that city. Transferred to the Adelphi in London it ran for ten months, where it earned Boucicault-once royalties, touring company franchises and acting fees were taken into account-some $£ 23,000$ (at present rates $£ 11$ million; US\$17,500,000; NZ\$21 million). Queen Victoria and Prince Albert went to see it three times between February and March 1861. In late August of that year they were guests of the Herbert family at Muckross House, ${ }^{35}$ specifically so the Queen could see the Lakes of Killarney, a favourite eighteenth- and nineteenth-century tourist destination and the setting for The Colleen Bawn, but a place where, as Boucicault subsequently quipped, the murder of Ellen Scanlan (nee Hanley-The Colleen Bawn) did not take place. ${ }^{36}$

Though Boucicault changed the setting, he based the plot and the characters on what was known from the newspapers, novels and operetta about the people involved. Ellen, who was 15 at the time she was murdered, had been cared for by her uncle after her mother died. Reputedly of a "lively disposition" and a great beauty, she had attracted the attention of John Scanlan, of Ballykehan House, near Bruff, County Limerick, who enticed her to marry him. But he soon tired of her, and after co-opting his servant Stephen Sullivan, planned her murder. She was taken out on the Shannon, beaten, shot, stripped and her body dumped in the river. Six weeks later her body washed up at Moneypoint, Kilrush. Both men were soon caught, and both were hanged, though it was commonly believed that Scanlan, because of his social standing and because he had been defended by Daniel O'Connell, would have his sentence commuted to life imprisonment. ${ }^{37}$ The trial was reported in the London Times. By the time Boucicault came to adapt the story of Ellen Scanlan for the stage in 1860, it had already given Gerald Griffin the plot for his three-volume novel The Collegians (1829); Thomas Egerton Wilkes the book for his light opera, Eily O'Connor or The Banks of Killarney (1837); and William Carleton the plot for his novel Willy Reilly and His Dear Colleen Bawn (1855), the last going into some 30 editions. For Boucicault, however, the Colleen Bawn was an important first. As he explained to his New York audience at its premiere: "I had long thought of writing a play from material gathered from my native country, but this is the first time I ever tried it." 38

Though some of the enormous international success of the play can be attributed to Boucicault's skilful plotting, much of its success, particularly in the colonies, can be attributed to the delineation of its characters. Like the work of his Irish precursors, Richard Steele (16721729), George Farquhar (1677-1707), Thomas Sheridan (1719-1788), Oliver Goldsmith (1728-1774), Richard Brinsley Sheridan (1751-1816) and John O'Keeffe (1747-1833), Boucicault constructed characters who found witty ways of negotiating their stigmatized position in society even as they subversively laughed off English pretension. To attend an Irish 
play in the colonies was to see institutional power challenged, class structures confounded, and justice mischievously triumph.

\section{The Dunedin Performance of The Colleen Bawn}

The Dunedin premiere, which opened at the Theatre Royal on 6 August 1862, drew a notice from the Otago Witness and a notice and a lengthy review from The Otago Daily Times. ${ }^{39}$ The Witness for the most part simply observed that: "The piece, which is full of thrilling situations and startling effects, was played with much spirit and was carried through in a manner that afforded unqualified pleasure to the crowded audience." ${ }^{40}$ But the Daily Times review, after reminding its readers that The Colleen Bawn was an internationally famous play which "had been performed in London alone for 700 nights" and which "is said to have brought to its author the enormous sum of $£ 35,000$," remarked the Irishness of the local production by observing: "The scenic arrangements, taking into consideration the comparatively limited resources of a provincial theatre, were admirable, and reflected great the greatest credit on the artist, Mr Manly. The Scene of the Lake of Killarney, by moonlight, was particularly beautiful, and the illusion was almost complete." Equally commended, though the reviewer's phrasing was somewhat formulaic, were the performances of the major roles: "The heroine of the play, the Colleen Bawn, was personated by Mrs Holt ... in a manner deserving of very great praise. Mr Holt, as Myles Na Coppaleen, sustained his part very effectively. The character abounds with the ready wit and sagacity peculiar to the Irish peasantry, to which Mr Holt did ample justice." 41

A somewhat surprising omission from the review, given the frequency of its occurrence elsewhere, is an assessment of the actors' mastery of "the brogue," the more so given that Myles na Coppaleen's speech is marked by Hiberno-English and transliterations from the Irish. But what is important here, regardless of the strengths and weaknesses of the Dunedin premiere and the critics' views, is the audience's performance of civility. It was now possible for a person from Dunedin to attend an internationally renowned Irish play that had been seen by the Queen three times; a play that was set in a location famous for its beauty which had been visited by the Queen; a play that was being staged in a tastefully appointed venue by a professional company with international experience barely two-and-a-half years after its New York premiere. What such an occasion demanded was appropriate dress and respectful behaviour; what it encouraged was shared enjoyment and friendly discussion about plot, character, costumes, setting and performance.

The first Dunedin season of The Colleen Bawn ran from 6 to 9 and from 11 to 14 August 1862, with revivals on 15, 19 and 20 November. On 27 and 28 November the Royal Princess Theatre, doubtless prompted by its rival's box office success, staged The Lily of Killarney, a "romantic opera" based on The Colleen Bawn with music by Julius Benedict and libretto by Dion Boucicault and John Oxenford. ${ }^{42}$ So popular and so associated with merchandising had this opera become that the most fashion-conscious ladies of the audience might have been tempted to purchase "Lily of Killarney stays" from Cashel House, Christchurch, ${ }^{43}$ or Colleen Bawn cloaks from the Dunedin firm of Hugh Kirkpatrick and Co. ${ }^{44}$ to wear at the 27 November Dunedin performance, advertised as "the first production in the Southern hemisphere. ${ }^{, 45}$ Whether or not these ladies wished to identify with the heroine is a moot point; but what seems certain is their wish to engage in a performance of metropolitan cultural mores that had been promoted by advertising and sanctioned by the society gossip columns of the London press. Whether with undergarment or cloak, the Colleen Bawns in the Dunedin audience in 1862 were playfully ensuring that they would not be upstaged by the leading lady on the other side of the footlights. 
While such merchandising is indicative of the rapid embourgeoisement of the Victorian theatre in general and the extent to which it quickly became associated with international celebrity, it was particularly the case in Dunedin. By the time the Princess Theatre and the Theatre Royal were built, their Australian precursors were well on the way to establishing themselves as ornate neoclassical temples to "rational enjoyment." As Ken Stewart has pointed out, from the 1850s, for example, in both Sydney and Melbourne, an increased proportion of the upper and middle classes amongst the new audiences brought the colonial theatre still closer to its London counterpart. Husbands and wives went to the play to meet there, and to take up their place in a class hierarchy emblematized by the seating arrangements. Discussion of plays and performers became part of ordinary middle-class conversation to an extent that would have been impossible in the earlier period, when, for example, a greater proportion of the audience were single men in search of diversion, and theatres were less comfortable. ${ }^{46}$

This performance of civility proceeded even more rapidly in Dunedin. By 12 August 1862, for example, the Princess Theatre, which had begun life as a converted horse bazaar as recently as 5 March of the same year, was reopening after extensive refurbishment. As the Otago Daily Times proudly reported:

The alterations have been extensive indeed; in fact, they have gone to the extent of an entire reconstruction of the house, which is now one of the prettiest and most comfortable of colonial theatres. The interior is decorated with remarkably good taste, lightness and harmony of color being the chief characteristics and when illuminated by the large and handsome chandelier which hangs from the roof, the house had a charmingly elegant and cheerful appearance. ... There was a large and highly respectable audience every seat being occupied in pit, dress circle, and private boxes; and it was pleasant to notice how thoroughly the gentle public seemed to enjoy themselves. This enjoyment was in no small degree contributed to by the excellent construction of the house, which admits of a good view of the stage from every part; the comfortable, well-stuffed seats, and the well-managed arrangements by which everyone was shown to his seat, without confusion or crowding. ${ }^{47}$

It is not surprising, then, that the management felt sufficiently confident in their venue to stage the southern hemisphere premiere of a light opera that had proved a major attraction in London and New York.

While The Colleen Bawn and The Lily of Killarney were the obvious Irish highlights of the 1862 Dunedin season, other offerings included 12 performances of Boucicault's adaptation of Scott's novel, Jessie Brown: or the Relief of Lucknow; eight of his The Octoroon; six of Buckstone's Green Bushes; six of Lover's The Happy Man; five of Boucicault's The Poor of London; four of his The Corsican Brothers; two each of Knowles's The Hunchback and William Tell, Boucicault's The Poor of London and Used Up, Coyne's The Queen of Abruzzi, Sheridan's The Rivals and Brougham's His Last Legs; and single performances of Banim's Damon and Pythias, Bayly's The Cork Leg and Perfection; or the Lady of Munster, Coyne's The Willow Copse, Falconer's The Rose of Castille, Sheridan Knowles's The Wife, Boucicault's London Assurance and Butler's The Irish Tutor. ${ }^{48}$

Of course, it is one thing to diligently compile a list of playwrights born in Ireland and plays presently known as Irish; it is quite another to attempt to determine what was known about the ethnicity of playwrights in Dunedin in 1862 and what significance might be attached to this knowledge. One argument is that the staging of The Colleen Bawn, with its plot based on an Irish event, set in one of the most famous tourist destinations in Ireland, with all the "good" characters in one way or another speaking "the brogue," would at least have alerted the Dunedin audience to the fact that Boucicault was Irish. Another is that the Dunedin audience, given the gold rush, comprised people from a wide range of backgrounds and places, some of 
whom had well-established connections with Dunedin. The ethnicity of Sheridan Knowles offers a case in point. While neither the Southland Times nor the Otago Daily Times, in reporting the dramatist's illness and death in January 1863, mention that he is Irish, the Empire (Sydney) acknowledged the Sheridan blood in his veins, ${ }^{49}$ while the Northern Whig, whose obituary was reprinted in newspapers like the Portland Guardian and Normanby General Advertiser, included details of his birth in Cork and aspects of his life in Ireland ${ }^{50}$ Portland, Victoria was one of several Australian ports of embarkation for Dunedin during the Otago gold rush that had strong shipping and commercial links prior to $1862 .{ }^{51}$ Finally, writers like Samuel Lover (1797-1868) and Edmund Falconer (1814-1879) were known as Irish, if not for their plays, then certainly for their other works or their professional careers. Lover's novels, Rory $O$ ' More: A National Romance (1837) and Handy Andy: A Tale of Irish Life (1842), as well as his songs such as "Molly Bawn" and "The Four-leaved Shamrock," subsequently collected into a popular entertainment called Irish Nights, unmistakably declared him Irish; while Falconer's "Killarney," one of the most popular songs of the nineteenth century and his 1862 play Peep o Day, ${ }^{52}$ also advertised as Savoureen Deelish, had the same effect.

It is demonstrably evident that by the end of 1862 not only theatre but also Irish theatre - in the sense of plays featuring Irish characters and plays by Irish playwrights - was well established in Dunedin. For example, letters to the Editor protesting the theatre's evil influence, once accorded a measure of respect, were increasingly given short shrift. One of the most notable is a 2200-word rebuttal of "Enquiry's" protest at the simultaneous revival of The Colleen Bawn and the refurbishment of the Princess Theatre. Arguing that "the tendency of most plays is a moral one," and that the stage was the place where vice was punished and virtue rewarded to the edification of the playgoer, the Editor instanced The Colleen Bawn as exemplary of the way in which "the deserving are made happy, the would-be murderer (Danny) is killed,- the weak Hardress suffers an infinity of agony so also his proud mother; and the villain Cregan is baffled at every point." "The stage," he contended:

has received the warmest support from the best and wisest of all lands. It is an institution that continues to flourish, and shows no sign of waning. No one can pretend that its support is confined to the immoral portion of society; crowned heads and mitred clergymen have delighted to up-hold it. The Queen, whose moral sense is of the highest, and who has many times gone out of her way to evince her unqualified disapproval of practices that incline to the immoral, is an ardent and constant supporter of the stage. She loves the art; she approves it as ennobling, and whenever she has had the opportunity, has encouraged its followers. Even from the pulpit the stage has been upheld. If we mistake not Canon Stowell, Dr. Chalmers, Kingsley, and Sydney Smith have spoken of it in highly laudatory terms. ${ }^{53}$

Dunedin, it was evident, had every right to be proud of its theatres as cultural institutions providing morally improving rational entertainment and as venues where polite behaviour, followed by cultivated discussion, fostered the performance of civility.

\section{The Colleen Bawn-Local and International Legacies}

That the theatre continued to flourish in Dunedin to the extent that the city could justifiably lay claim to being at least at the forefront of, if not the theatrical capital of, the Australasian colonies, is supported by a rough calculation of the number of theatre seats per head of population 30 years after the Theatre Royal and the Princess were built - a calculation for the year 1891, for example, places the city ahead of Auckland, Sydney and Melbourne. ${ }^{54}$ That Irish theatre continued to flourish is not only borne out by the hundreds of revivals of Irish plays and the numerous performances of new ones that would follow in the ensuing decades, but by the fact that in 1885 the most famous Irish actor, dramatist and impresario of the nineteenth 
century, Dion Boucicault, as I have detailed extensively elsewhere, ${ }^{55}$ would visit Dunedin to favour the city with a definitive interpretation of Myles na Coppaleen from The Colleen Bawn. $^{56}$

As for the play itself? In 1905 the Wairarapa Daily Times, under the headline "The Colleen Bawn: An Interesting Reminiscence," was certain that "playgoers with interest in the theatre" would hear "with genuine regret the news of the death of 'Father Tom' - otherwise $\mathrm{Mr}$ Charles Henry Stephenson at the age of eighty two ... the last living male player in the memorable English cast of The Colleen Bawn, produced with astonishing - nay, phenomenalsuccess at the Adelphi Theatre nearly forty years ago. ${ }^{, 57}$ Predictably, given its popularity, The Colleen Bawn eventually made its way from stage to screen. In 1911 an Australian company and the American Kalem Film Company, independently of one another, produced versions for the cinema. These were followed by two further British adaptations, one of the play in 1924 and one of the opera in 1929. And as recently as 2010, the Project Arts Centre in Temple Bar, Dublin, revived The Colleen Bawn for a season running from 21 July to 4 September, playing to packed houses still entranced by what was engagingly described as "love triangles, dark deeds and a load of old blarney." good citizens of Dunedin yielded to the charms of theatre, and particularly Irish theatre, as they debated ways to make their city internationally renowned for its "liberal and enlightened principles."

\footnotetext{
${ }^{1}$ Otago Witness, May 31, 1862, 5 and July 12, 1862, 5.

2 Otago Witness, July 12, 1862, 5. Not, however, a view shared by everyone: "The following extract from a letter written by a gentleman lately in the Government service here, to a friend in Sandhurst, will be read with some interest:- 'There are two theatres got up in the slight cardboard and gilt style. Any quantity of calico and paper, but no stability and comfort. To the Criterion Hotel is attached the Royal under the joint auspices of Clarence Holt and Madame Duret, where they are producing most violent tragedies and sensation dramas. At the Provincial (Jones') the old Princess Theatre was built in the horse Bazzar, which was screened off at night for the theatre, (not moving the horses). I was much reminded of Astley's when I went for the first time. The stables and horses, however, have been banished, and a pretty new theatre built under the lessee-ship of Tom Fawcett and his brother, whose star is Charles Young." "Otago Witness, October 11, 1862, 6.

${ }^{3}$ Of the considerable scholarship, the most authoritative are Christopher Morash, A History of Irish Theatre 1601-2000 (Cambridge: Cambridge University Press, 2002), and Allardyce Nicol, A History of English Drama 1660-1900, 4 vols (Cambridge: Cambridge University Press, 1975).

${ }^{4}$ That is spoken drama.

${ }^{5}$ Daily Southern Cross, July 8, 1856, 3.

${ }^{6}$ See Richard Schoch, Queen Victoria and the Theatre of Her Age (London: Palgrave Macmillan, 2004).

${ }^{7}$ Quoted in Peter Downes, Shadows on the Stage: Theatre in New Zealand-The First 70 Years (Dunedin: John McIndoe, 1975), 33.

${ }^{8}$ An Act taking into account the Dramatic Writings Bill, 1830; Dramatic Property Act, 1833; Bill to amend the Laws Relating to Dramatic Literary Property, 1833.

${ }^{9}$ J. Moody, Illegitimate Theatre in London, 1770-1840 (Cambridge: Cambridge University Press, 2000 ), 164.

${ }^{10}$ Quoted in Ernest Bradlee Watson, Sheridan to Robertson: A Study of the Nineteenth-Century London Stage (Cambridge: Harvard University Press, 1926), 43.

${ }^{11} \mathrm{~S}$. T. Coleridge is alleged to have said that seeing Edmund Kean act was "like reading Shakespeare by flashes of lightning": Table Talk, April 27, 1823.

12 The John Wycliffe carried 97 emigrants and arrived on 23 March 1848; the Philip Laing carried 247

passengers and arrived on 15 April 1848. All told, there were 93 children under 14 years of age at first settlement.

${ }^{13}$ Downes, Shadows on the Stage, 11. The play was apparently a version of The Kiss; or the Lawyer Outwitted, written by Stephen Clarke and first produced at the Lyceum Theatre, London, in 1811.

${ }^{14}$ Downes, Shadows on the Stage, 14-16. Typical of provincial theatres of the period, The Royal Victoria Theatre, Wellington, closed temporarily on 14 November 1843 , opening only briefly for a short season under a Mr L. Davies, an actor "from Sydney, Melbourne and London" before it ceased to be used as a theatre. It eventually became a storehouse for the Ship Hotel. The initial closure seems to have been brought about by a dispute between James Marriott and the proprietors of the Ship.
} 
${ }^{15}$ Downes, Shadows on the Stage, 17: See Alfred J. Cripps and Humphrey Hall, The Romance of the Sydney Stage (Sydney: Currency Press, 1996), 247 for a reproduction of a sketch of the Buckingham family taken from the Illustrated London News, 1855.

${ }^{16}$ The play was apparently Molière's Lovers' Quarrels (1656), his second full-length play in verse.

${ }^{17}$ Downes, Shadows on the Stage, 17-21. The Fitzroy Theatre opened on 12 February 1844 . The theatre, which became known as the Shortland Crescent Royal Victoria Theatre, remained open until November 1844, when falling box-office returns, doubtless due to the economic depression that gripped New Zealand in the early 1840 s, forced its closure.

${ }^{18}$ See Lyttelton Times, July 17, 1858, 4; July 24, 1858, 4; and July 31, 1858, 5.

${ }^{19}$ Downes, $40-41$.

${ }^{20}$ Daily Southern Cross, November 17, 1857, 3.

${ }^{21}$ Otago Witness, August 25, 1855, 2.

${ }^{22}$ Otago Daily Times, January 10, 1862, 5; Otago Witness, January 11, 1862, 5.

${ }^{23}$ Otago Witness, April 17, 1858, 4. The article continued: "We were glad to see that the concert was so generally patronized; and we take it as evidence that the community, as well as ourselves, would desire to see such nights of pleasant entertainment more frequent among us. Concerts, if properly conducted, would, we are confident, be countenanced and well supported."

24 "Social and Domestic," Otago Witness, January 11, 1862, 5. Dunedin had a population of approximately 2000 people in 1861, the year significant quantities of gold were discovered.

${ }^{25}$ Otago Witness, January 11, 1862, 5.

${ }^{26}$ Knowles, who was born in Cork in 1784, died in 1862. The text of The Hunchback is available at http://www.gutenberg.org/cache/epub/3480/pg3480.txt.

${ }^{27}$ Otago Daily Times, January 31, 1862, 3.

${ }^{28}$ It was Macready's performance in the title role of Sheridan Knowles's William Tell (11 May 1825) that first endeared him to the London public.

${ }^{29}$ Available online at http://babel.hathitrust.org/cgi/pt?id=nyp.33433068251309;seq=7;view=1up;num=1.

${ }^{30}$ Jane W. Steadman, "General Utility: Victorian Author Actors from Knowles to Pinero," Educational Theatre Journal 24, no. 3 (1972), 292.

${ }^{31}$ Otago Daily Times, August 11, 1862, 4.

${ }^{32}$ Otago Witness, February 15, 1862, 5.

${ }^{33}$ Otago Witness, May 31, 1862, 5.

${ }^{34}$ Otago Daily Times, July 11, 1862, 6.

${ }^{35}$ The Queen's visit to Ireland was reported in Otago Witness, October 19, 1861, 4. See also http://www.muckross-house.ie/queen-victorias-visit-1861.html.

36 "Mr Dion Boucicault on Ireland and Irishmen," Auckland Weekly News, October 17, 1885, 7.

${ }^{37}$ See http://www.clarelibrary.ie/eolas/coclare/people/bawn.htm.

${ }^{38}$ Dion Boucicault, New York Tribune, March 30, 1860, 8, quoted in Deirdre McFeely, Dion Boucicault: Irish Identity on Stage (Cambridge: Cambridge University Press, 2012), 13.

${ }^{39}$ There was a brief notice in the Otago Daily Times, August 7, 1862, pointing out that because "at the close of the performance, Mr Holt asked for indulgence for certain slight errors owing to its being the first night," the reviewer would "therefore postpone till tomorrow a detailed criticism, so as to enable us to judge more fully by a second inspection."

${ }^{40}$ Otago Witness, August 9, 1862, 4.

41 "The 'Colleen Bawn' at the Theatre Royal," Otago Daily Times, August 8, 1862, 5.

${ }^{42}$ Hard-bound copies of the complete score were on sale at Varty's Musical Repository in Auckland for 35s as early as 16 May 1862: Daily Southern Cross, May 16, 1862, 3.

${ }^{43}$ Press, October 11, 1862, 14, and October 18, 1862, 14.

${ }^{44}$ Otago Daily Times, June 24, 1862, 3.

45 "Royal Princess Theatre, Grand Night!!!, Thursday $27^{\text {th }}$ November, 1862, Being the Benefit for Madame Carandini," Otago Daily Times, November 25, 1862, 6.

${ }^{46}$ Ken Stewart, "Theatre, Critics and Society," in The Australian Stage: A Documentary History, ed. Harold J. Oliver (Kensington: University of New South Wales Press, 1984), 58.

${ }^{47}$ Otago Daily Times, August 12, 1862, 5.

${ }^{48}$ As advertised in the Otago Witness and the Otago Daily Times for 1862 . That the list contains only male Irish dramatists is largely due to the fact that the work of the few Irish women dramatists of the period did not achieve commercial production. See Angela Bourke et al., eds., The Field Day Anthology of Irish Writing: Irish Women's Writing and Traditions, Vol. 5 (Cork: Cork University Press in association with Field Day, 2002), 774 and Seamus Deane et al., eds., The Field Day Anthology of Irish Writing, Vol. 1 (Derry: Field Day Publications, 1991), 500-507. 
${ }^{49}$ Empire, February 26, 1863, 8.

${ }^{50}$ Portland Guardian and Normanby General Advertiser, April 30, 1863, 3.

${ }^{51}$ Otago Witness, November 6, 1858, 5 is the earliest of several hundred announcements of shipping between Portland and Dunedin; Otago Witness, December 25, 1858, 3, for example, contains a notice that the Dunedin branch of the Union Bank of Australia is willing to grant drafts on its branch in Portland.

${ }^{52}$ Otago Daily Times, January 9, 1863, 3 advertises a production at the Princess Theatre on 11 January 1863; there is a further announcement in Otago Daily Times, January 14, 1863, 3; Otago Daily Times, January 17, 1863, reported that Peep o' Day Boys went better than ever, that "it was a capital house" and that "the dress circle and the side boxes were comfortably filled."

${ }^{53}$ Otago Daily Times, August 11, 1862, 4.

${ }^{54}$ By 1891 , Dunedin, with a population of 50,326, could claim 2830 theatre seats, which meant that there was one theatre seat available for every 18 persons. Auckland, with a population of 52,432 and 1200 theatre seats, had one theatre seat for every 43 persons; Melbourne, with a population of 445,200, had one theatre seat for every 44 persons; and Sydney, with a population of 383,400, had one theatre seat for every 41 persons.

${ }^{55}$ See R. Kuch, "Irishness, the Australasian Colonial Theatre and the Public Sphere," in B. Patterson and K. Patterson, eds., Ireland and the Irish Antipodes: One World or Worlds Apart? (Melbourne: Anchor Books, 2010), 203-16; R. Kuch, "'Irishness' on the New Zealand stage 1860-1920: The Boucicault and Allgood tours," Journal of Irish and Scottish Studies: Nations, Diasporas, Identities 4, no. 1 (2010) 99-118; R. Kuch, "The Irish and the Australasian Colonial Stage: Confrontation and Compromise," Australasian Journal of Irish Studies 10 (2010), 105-18.

${ }^{56}$ See Otago Daily Times, October 30, 1885, 3: "Probably no sensational drama has been so much murdered in its day, and none has better elements of popularity if properly treated. Many who have seen the piece with painful frequency would be ready to admit that so far as regards Myles-na-Coppaleen they had never really seen it until last night. The author's representation of this character was like his other portraits of the Irish peasantry, perfect."

${ }_{57}^{7}$ Wairarapa Daily Times, July 5, 1905, 2.

${ }^{58} \mathrm{See}$ http://www.projectartcentre.ie/programme/whats-on/1079-the-colleen-bawn. 